\title{
DEMOCRATIC VALUES AND DIGITAL SKILLS OF STUDENTS IN HIGHER EDUCATIONAL ESTABLISHMENTS OF POLAND AND UKRAINE
}

\author{
Mariya Leshchenko1, LarysaTymchuk², Nataliia Pavlenko ${ }^{3}$, and Larysa Ruban ${ }^{2,1}$ \\ ${ }^{1}$ The Jan Kochanowski University in Kielce, Poland \\ darlyngpetra18@gmail.com \\ ${ }^{2}$ Taras Shevchenko National University of Kyiv, Ukraine \\ lucky.clio2017@gmail.com; mlarissa@urk.net \\ ${ }^{3}$ Poltava V.G. Korolenko National Pedagogical University, Ukraine \\ nataliiapavlenkonet@gmail.com
}

\begin{abstract}
The subject of the paper is evaluating and comparing the activity of using digital technologies for the realisation of democratic values by students of Polish and Ukrainian higher educational establishments: rights to freedom of access to information; tolerant communication with other people; awareness of the values of solidarity, equality.The study was carried out at Maria CurieSklodowska University in Lublin (Poland), The Jan Kochanowski University in Kielce (Poland), Radom Academy of Economics (Poland), Taras Shevchenko National University of Kyiv (Ukraine), Poltava V.G. Korolenko National Pedagogical University (Ukraine). Based on the survey results, the quantitative and qualitative analysis of digital technologies used in the development of democratic ideals and social activity of youth are carried.The results obtained are typologically common for students of both Polish and Ukrainian higher educational establishments. The paper provides recommendations for teachers of higher educational establishments on the use of digital technologies to support the development of students' democratic values in formal and non-formal learning and draws attention to the problem of forming digital critical competence of students.
\end{abstract}

Keywords: democratic values; digital skills; digital critical competence; democratisation; educational process.

\section{Introduction}

In today's conditions of transformation, globalisation and digitalisation of society, significant changes are taking place in the process of formation of value orientations of young people. The development of interests, beliefs and values is strongly influenced by digital technologies. Youth community is the most open to technological change and innovation. The availability of new software and smart applications expand the ability to realise young people's democratic rights through developing cognitive, creative, communicative and collaborative skills, affect their processes of worldview and self-expression.

Democratic values mean social values that provide a democratic way of thinking and human activity (Kostriukov, 2004), the embodiment of humanism, spirituality, tolerance, and freedom of speech (Hoshovska, 2013), personal and individual human freedom, real conditions and opportunities for expression of socio-political activity, the right to act (choose and elect) in one's own opinion, freedom of speech, conscience, etc. (Ordina, 2009). According to the researchers, basic democratic values are freedom, equality, openness, dignity, tolerance, solidarity.

In the European Union Fundamental Rights Map, these and other values are not only outlined but also specified (Karta praw, 2016). The concept of Freedom is interpreted in the document as: the right to Freedom and personal security, respect for the life of personal and family, protection of personal data; Freedom of thought, conscience and religion; Freedom of expression and information; Freedom of assembly and association, etc. Equality is interpreted as equality before the law, non-discrimination (gender, race, colour, ethnic or social background, genetic characteristics, language, religion or beliefs, political and other views, national minority, property status, ancestry, disability, age or sexual orientation); cultural, religious and linguistic diversity, equality between women and men, children's rights, the rights of the elderly, integration of persons with disabilities, etc. Solidarity means the right of employees to information and advice in the context of entrepreneurship, the right to collective bargaining and collective action, including the right to strike and other social rights and guarantees. Democratic values are also outlined in the documents concerning such rights and opportunities as: the right to vote and participate in elections, the right to access documents, the right to petition, the freedom of movement and residence, etc.

The issues of development of the value system are relevant for the world community. It is worth mentioning the results of the scientific search "The European Values Study (EVS)", obtained in the framework of an international long-term program of study of fundamental human values (The European

Leshchenko, M., Tymchuk, L., Pavlenko, N., \& Ruban, L. (2020). Democratic values and digital skills of students in higher educational establishments of Poland and Ukraine. Advanced Education, 105-115. DOI: 10.20535/2410-8286.208316 
Values Study, 2019). The results represent the beliefs, preferences, opinions, positions, values and attitudes of citizens across Europe. This is an exceptional research project that answers the question of how Europeans perceive the nature of life, family, work, religion, politics and society.

The European Values Study was launched in 1981, when surveys were conducted using standard questionnaires among thousands of EU citizens. Every nine years the study is repeated in different countries. The fourth wave in 2008 covered at least 47 European regions, from Iceland to Georgia and from Portugal to Norway. In total, about 70,000 people were interviewed. An in-depth analysis of the results of 1981, 1990, 1999 and 2008 in Western and Central Europe confirmed the phenomenon of a gradual deep transformation of the value system, their dependence on the stage of socio-economic development and historical factors specific to the people.

Since 2017, this research in Europe has been conducted by EVS in collaboration with WVS and with the participation of SERISS. A new wave of research from 2017 brought new information on the subject, making it also possible to analyse the impact of economic crises on people's values around the world. WVS researchers have identified that empowering ordinary citizens enables and motivates people to demand democracy, leading to significant changes that empower people to lead their lives. The spread of values of self-expression leads to the emergence of democratic institutions that enable people to enjoy greater freedom and to choose the right political system (World Values Survey, 2019).

The issue of the development of personality values in different historical periods was studied by eminent philosophers, educators, psychologists and artists (Gaisina, et.al, 2015, Denek, 2008.). A considerable number of scientific papers are devoted to the problem of formation of democratic values of youth. Conceptual approaches to the use of digital technologies in the educational reality of open education are partly proved in the works of Bykov \& Leshchenko (2016), Tymchuk (2016), Hrynko (2019). The subject of the study has been theoretical foundations of digital humanistic pedagogy of open education (Bykov and Leshchenko, 2016), design of digital narratives in preparation of Masters of education (Tymchuk, 2016), use of digital narratives in teaching English as a foreign language to university students and use of electronic social networks in teaching students (Hrynko, 2019).

The various aspects of digital technologies implementation are highlighted in the papers of foreign scientists: Johnson (2007), King (2019), Nachmias, Mioduser, and Shemla (2001), Blayone et al (2018). However, there is a lack of research on the use of digital technologies to support the realisation of students' democratic values and rights.

\section{Research aims}

This paper aims at evaluating and comparing the activity of using digital technologies for the realisation of democratic values by students of Polish and Ukrainian higher educational establishments.

To reach the aim, the following tasks were set:

1. To find out the types of digital technologies activities Polish and Ukrainian students use to realise their rights to freedom of access to information and for tolerant communication with other people

2. To analyse the results of Polish and Ukrainian students participation in specially created online social networks in order to organise joint social activity and to verify their awareness of the values of solidarity, equality;

3. To substantiate recommendations on the use of digital technologies to support the development of students' democratic values of formal and non-formal learning.

In the study, we hypothesise that using digital technologies could benefit to the realisation of students' democratic values and this experience could create conditions for the democratisation of the digital educational space of universities

\section{Methods}

\section{Research Design}

The study presents mixed of theoretical and empirical research framework. In our study, we used the following theory-based research methods: a method of comparative-pedagogical analysis of the results of international studies, critical analysis of foreign and national scientists' works was used to determine the essence of the basic concepts of the research; terminological analysis, which provided the disclosure of the essence of the pedagogical phenomena studied by identifying and clarifying the meanings of the main categories. Among empirical methods we employed: an analytic search method for finding out the opportunities how to use digital technologies in the development of democratic values; developed the criteria for determining the activity in using digital technologies for the realisation of democratic values by students of Polish and Ukrainian higher educational establishments; a survey was used for quantitative and qualitative 
analysis of students' behaviour in the digital space; a method of pedagogical prediction was used to formulate recommendations on the use of digital technologies in the development of democratic values of university students.

\section{Participants}

The study involved 237 students from three Polish universities: Maria Curie-Sklodowska University in Lublin, The Jan Kochanowski University in Kielce (Branch Office in Piotrkow Trybunalski) and Radom Academy of Economics. The survey at Polish educational establishments was also conducted by one of the Ukrainian authors as a part of the Lane Kirkland Scholarship Program in the 2018-2019 academic year(Biuletyn, 2018). 230 students from two universities of Ukraine also participated in the study: Taras Shevchenko National University of Kyiv and PoltavaV.G. KorolenkoNationalPedagogicalUniversity. This research complies with the research ethics, all participants took part in this research on a voluntary basis and were not forced in any way.

Data collection tools

In order to identify the activity in using digital technologies for the realisation of democratic values by students of Polish and Ukrainian higher educational establishments, the questionnaire was composed. It included questions that helped to identify various aspects of the problem. The questionnaire is based on the approach implemented by Polish scientists in the EU Kids Online 2018 study (Polskie badanie EU Kids Online, 2018).

The questionnaire includes closed-ended questions aimed at identifying various aspects of students' behaviour in the digital space, which allow them to analyse their awareness of openness of information space and activity in it, the ability to communicate freely and express their own point of view, freedom of thought and creativity, solidarity, tolerance, civic activism and other manifestations of democratic values.

\section{Data analysis criteria}

The survey results were analysed with the application of mathematically calculated median meaning of answers. We assessed them in positive and negative connotations and established the connection between the personal discourse and character of activities mentioned by students. We evaluated the impact of activities by cognitive, communicative, and creative criteria suggested by the authors of digital humanistic pedagogy (Bykov and Leshchenko,2016) on the evaluation of digital impact on the personal development.

The cognitive criterion was used to identify young people's ability to seek, perceive and evaluate information, which testified the freedom of access to information and the freedom to choose it. Its features included: the ability to find relevant information on relevant TV channels, websites, social networks and other Internet resources; students' interest in social processes occurring in the society, their region of residence.

Abilities identified with this criterion helped to find out how often a young person searched for and viewed on the Internet and on TV of local and foreign news, information about life in their region and in their community, thus realising the possibility of free access to information and freedom choices (information resource, content, etc.). Such democratic value as Freedom is connected with freedom of access to information. The degree of realisation of this value is evidenced by the active use of search engines, the frequency of searching the Internet for information from various information sources, and evaluating its authenticity.

The communicative criterion was used to identify youth electronic networking skills that manifest themselves in a person's ability to integrate in the process of free exchange of thoughts and opinions, and proved the right to their own point of view, free expression of their individuality and uniqueness, as well as manifested tolerance for ethnic, racial, age, gender, religious, physical diversity of other people.

This criterion includes: the ability to use the Internet, e-mail to communicate with people from other countries of the world; activity on social networks (a profile on social networks, the frequency of viewing and posting comments or own narratives, photos, videos); the availability of digital skills to use different services and portals, create digital narratives, post them in the network.

Thus, the communicative criterion identified the impact of technology on the development of democratic values related to the freedom to express one's own point of view and to disseminate information. Exactly these values are stated in international documents: "Everyone has the right to freedom of expression. This right encompasses the freedom of one's own views, as well as the receipt and dissemination of information and ideas without interference by state authorities and regardless of national borders. Freedom and pluralism of the media are respected" (Karta praw podstawowych Unii Europejskiej, 2016). The degree of realisation of this value is evidenced by the active use of the Internet, in particular e-mail, electronic social networks, mobile applications, for the realisation of communication with different people. Virtual network communication shows tolerance and equality, pluralism of thought and freedom of self-expression. 
Affirmation of equality and tolerance is influenced by Internet browsing of programs, films or other digital narratives on equality based on ethnic origin, social status, gender, age, skin colour, race, language, religion, beliefs, attitudes, national minorities, special needs, or sexual orientation.

The creative and active criterion was used to identify the ability to perform network interaction to complete a common task. This criterion includes the following skills: to use digital technologies to collaborate in organising social activities; to discuss online with others on socio-political topics; to take an active part in social online networks, for realisation of socially significant actions, events, etc.

The frequency of person's accesses to the Internet to engage in political campaigns, protests, or sign socially important petitions, or uses special applications to work together and perform a joint task, or work in a joint project is indicative of his/her awareness of the values of solidarity, equality and democracy.

One of the manifestations of the freedom value is freedom of assembly and association, which is that "everyone has the right to participate in a free, peaceful assembly, as well as in a free association at all levels, including political, trade union and public issues..." (King, 2019).Through the Internet and media, this value is developed through communication with different groups of people, selection, search, discussion and dissemination of information, online participation in various online communities, chats, online groups where people share their interests, hobbies, views.

Thus, the defined criteria made it possible to analyse the activity of using digital technologies for the realisation of democratic values by students of Polish and Ukrainian higher educational establishments were identified for the study.

\section{Results}

The analysis of the conducted studies showed that the development of democratic values of young people is connected with their virtual activity in the network. The study of the possibilities of the technology influence on the development of democratic values of young people in the information society was based on the analysis of the published research results.

The World YMCA has conducted research into the interests, values of young people and the challenges young people face in today's information societies. The results of the research in Poland, Ukraine, Belarus and Russia were presented during a scientific conference "Youth Speaks About Themselves Młodzieżmówi o sobie", organised in collaboration with the University of Warsaw. Researchers from this project and other speakers have emphasised that digital technology and the media are one of the powerful factors that influence young people's values, interests and attitudes. Scientists have found that one of the three main features of today's youth are their close relationship with the digital media space. "The concept of IT or digital generation" has been outlined in research reports in all countries. "The constant connection with virtual reality observed among young people is natural and facilitates communication, but at the same time can have a negative effect" (The European Values Study, 2019).

A report by Ukrainian scholars on the axiological foundations of social imperatives in the process of civil society formation in Ukraine states that in recent decades, due to the rapid development of IT, the media sphere has entered the daily life of young people, becoming the main source of knowledge about the world around them. Researchers say that in the information society, "media is one of the main factors responsible for shaping and transforming the value system" (Ordina, 2009).

The analysis of the conducted studies showed that the development of democratic values of young people is connected with their virtual activity in the network. The study of technology capabilities to support the development of democratic values in the information society was also based on the research by Deborah G. Johnson (2007), presented in Democracy, Technology, and Information Societies. On the basis of the analysis, the following statements of the scientist were distinguished, which became important methodological bases of the conducted research: Technology is a sociotechnical system with value characteristics; There is a relationship between technology and democratic values; Supporting the democratic values of the information society is ensured by appropriate education of ICT professionals and citizens' real knowledge of information democracies. Addressing these issues is important for the development of democracy in the information society (Johnson, 2007). The scientist's ideas that every technology is a product of people and its dissemination within democracy-related society have become the key to understanding the impact of digital technology skills on the development of youth democratic values.

In our study, the democratic values of youth were interpreted as personally meaningful rules of conduct in digital space to ensure democratic rights (freedom of access to information, equality, openness, tolerance, solidarity in the course of social interaction with others). The authors concluded that democratic values are the expected norms of social behaviour that affirm the ideas of a democratic society. In our research, the realisation of democratic values of young people was considered in the discourse of personally significant 
use of digital technologies to ensure freedom, equality, openness, tolerance, solidarity in the course of social interaction with other people. The formulated definition has become an important component of scientific research aimed at identifying the potential impact of technology on the expected democratic behaviour of young people during social interaction.

\subsection{The digital technologies activities for the realisation of democratic values by students of Polish and Ukrainian higher educational establishments}

The first question in the survey was about students' activity in searching for national and foreign news on the Internet. The results are presented in Table 1 (Source: Authors' own research).

Table 1. Search for national and foreign news on the network

\begin{tabular}{|c|c|c|c|c|c|c|c|c|c|c|c|c|c|c|c|}
\hline \multirow[t]{2}{*}{ Question } & \multicolumn{2}{|c|}{ 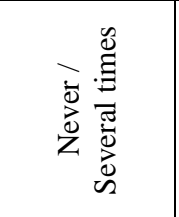 } & \multicolumn{2}{|r|}{ 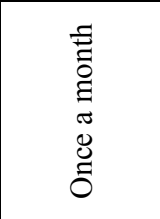 } & \multicolumn{2}{|r|}{ 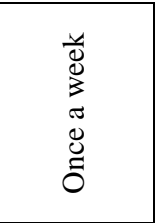 } & \multicolumn{2}{|c|}{ 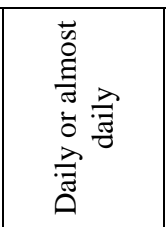 } & \multicolumn{2}{|c|}{ 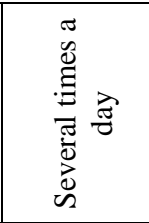 } & \multicolumn{2}{|c|}{ 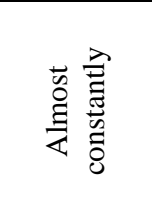 } & \multicolumn{2}{|c|}{ 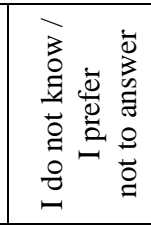 } & \multirow[t]{2}{*}{ } \\
\hline & $\mathrm{N}$ & $\%$ & $\mathrm{n}$ & $\%$ & $\mathrm{n}$ & $\%$ & $\mathrm{n}$ & $\%$ & $\mathrm{~N}$ & $\%$ & $\mathrm{~N}$ & $\%$ & $\mathrm{n}$ & $\%$ & \\
\hline \multirow{2}{*}{$\begin{array}{l}\text { I search and browse } \\
\text { national and foreign news } \\
\text { on the Internet }\end{array}$} & 24 & 10,13 & 46 & 19,41 & 39 & 16,46 & 69 & 29,11 & 13 & 5,49 & 41 & 17,30 & 5 & 2,11 & Poland \\
\hline & 19 & 8,26 & 21 & 9,13 & 30 & 13,04 & 95 & 41,3 & 19 & 8,26 & 46 & 20 & 0 & 0 & Ukraine \\
\hline
\end{tabular}

The study has shown that $29.11 \%$ of Polish and $41.3 \%$ of Ukrainian students search for information from the Internet resources of their country and foreign one every day or almost every day; $17.3 \%$ of Polish and $20 \%$ of Ukrainian students are almost constantly online, seeking the news. $16.46 \%$ of Polish and 13/04\% of Ukrainian students are interested in news once a week; $19.4 \%$ of Polish and $9.13 \%$ of Ukrainian students are interested in news once a month. $10.13 \%$ of Polish and $8.26 \%$ of Ukrainian students never look for news online. Increased activity of Ukrainian students in search of national and foreign news is explained the sociopolitical instability within the country.

The second question reveals how often students use electronic mail services. The data obtained are presented in Table 2(Source: Authors' own research).

Table 2. Use of e-mail

\begin{tabular}{|c|c|c|c|c|c|c|c|c|c|c|c|c|c|c|c|}
\hline \multirow[t]{2}{*}{ Question } & \multicolumn{2}{|c|}{ 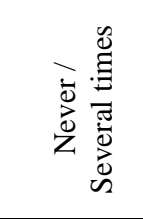 } & \multicolumn{2}{|c|}{ 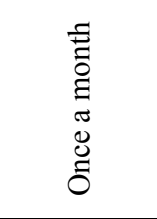 } & \multicolumn{2}{|r|}{ 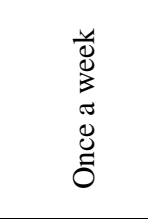 } & \multicolumn{2}{|c|}{ 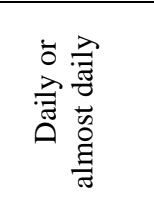 } & \multicolumn{2}{|c|}{ 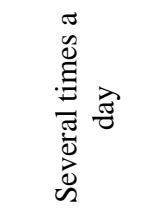 } & \multicolumn{2}{|c|}{ 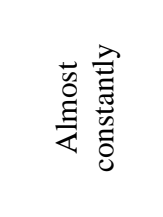 } & \multicolumn{2}{|c|}{ 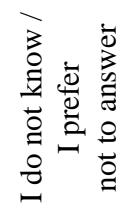 } & \multirow[t]{2}{*}{ 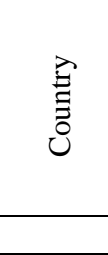 } \\
\hline & $\mathrm{N}$ & $\%$ & $\mathrm{n}$ & $\%$ & $\mathrm{n}$ & $\%$ & $\mathrm{n}$ & $\%$ & $\mathrm{~N}$ & $\%$ & $\mathrm{~N}$ & $\%$ & $\mathrm{n}$ & $\%$ & \\
\hline \multirow[t]{2}{*}{ I use e-mail } & 2 & 0,84 & 14 & 5,91 & 21 & 8,86 & 72 & 30,38 & 56 & 23,63 & 70 & 29,54 & 2 & 0,84 & Poland \\
\hline & 19 & 8,26 & 30 & 13,04 & 26 & 11,3 & 44 & 19,13 & 26 & 11,3 & 85 & 36,95 & 0 & 0 & Ukraine \\
\hline
\end{tabular}

The study has shown that $0.84 \%$ of Polish and $8.26 \%$ of Ukrainian students never or only several times use email. 5.91\% of Polish and 13.04\% of Ukrainian students review or send emails once a month and $8.86 \%$ of Polish and $11.3 \%$ of Ukrainian students review or send emails once a week. E-mail is used daily or almost daily by $30.38 \%$, of Polish and $19.13 \%$ of Ukrainian students; and e-mail is used several times a day by 23.63\% of Polish and 11.3\% of Ukrainian respondents. 29.54\% of Polish and 36.95\% of Ukrainian students use email almost constantly. $0.84 \%$ of Polish students did not answer this question.

The third question was related to the frequency of students using social networks. The results obtained are presented in Table 3(Source: Authors' own research).

None of Polish (0\%) and 3.47\% Ukrainian students have used electronic social networks or have used it several times. 5.91\% of Polish and $0.86 \%$ Ukrainian students use electronic social networks once a month; $12.66 \%$ of Polish and $0.86 \%$ of Ukrainian students use electronic social networks once a week. $26.58 \%$ of Polish and $18.26 \%$ of Ukrainian respondents use social networks on a daily or almost daily basis; $19.83 \%$ Polish and $18.26 \%$ Ukrainian students use the network several times a day; $34.18 \%$ of Polish and $55.65 \%$ of Ukrainian respondents are online almost constantly. $0.84 \%$ of Polish and $2.6 \%$ of Ukrainian students refused to answer this question. 
Table 3. Use of electronic social networks

\begin{tabular}{|c|c|c|c|c|c|c|c|c|c|c|c|c|c|c|c|}
\hline \multirow[t]{2}{*}{ Question } & \multicolumn{2}{|c|}{ 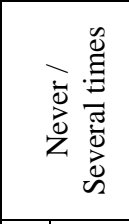 } & \multicolumn{2}{|c|}{$\begin{array}{l}\bar{\Xi} \\
\bar{\Xi} \\
\Xi \\
\tilde{J} \\
\delta \\
0 \\
0\end{array}$} & \multicolumn{2}{|c|}{ 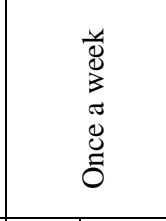 } & \multicolumn{2}{|c|}{ 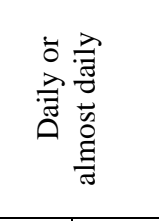 } & \multicolumn{2}{|c|}{ 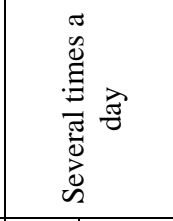 } & \multicolumn{2}{|c|}{ 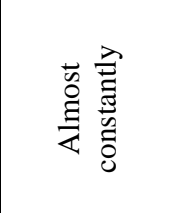 } & \multicolumn{2}{|c|}{ 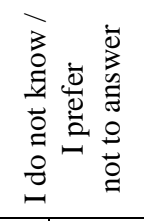 } & \multirow[t]{2}{*}{$\begin{array}{l}\vec{E} \\
\stackrel{\Xi}{0}\end{array}$} \\
\hline & $\mathrm{N}$ & $\%$ & $\mathrm{n}$ & $\%$ & $\mathrm{n}$ & $\%$ & $\mathrm{n}$ & $\%$ & $\mathrm{~N}$ & $\%$ & $\mathrm{~N}$ & $\%$ & $\mathrm{n}$ & $\%$ & \\
\hline \multirow{2}{*}{\begin{tabular}{|lll} 
I & use electronic social \\
networks
\end{tabular}} & 0 & 0,00 & 14 & 5,91 & 30 & 12,66 & 63 & 26,58 & 47 & 19,83 & 81 & 34,18 & 2 & 0,84 & Poland \\
\hline & 8 & 3,47 & 2 & 0,86 & 2 & 0,86 & 42 & 18,26 & 42 & 18,26 & 128 & 55,65 & 6 & 2,6 & Ukraine \\
\hline
\end{tabular}

The fourth question concerned the frequency young people have used the Internet to communicate with foreigners. The data obtained are shown in Table 4(Source: Authors' own research).

Table 4. Use of the Internet for international communication

\begin{tabular}{|c|c|c|c|c|c|c|c|c|c|c|c|c|c|c|c|}
\hline \multirow[t]{2}{*}{ Question } & \multicolumn{2}{|c|}{ 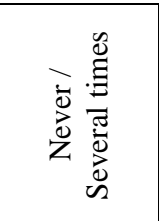 } & \multicolumn{2}{|c|}{$\begin{array}{l}\tilde{\Xi} \\
\bar{\Xi} \\
\Xi \\
\sigma \\
0 \\
0 \\
0\end{array}$} & \multicolumn{2}{|c|}{ 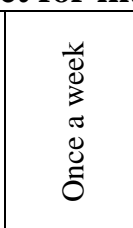 } & \multicolumn{2}{|c|}{ 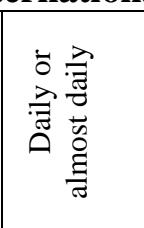 } & \multicolumn{2}{|c|}{ 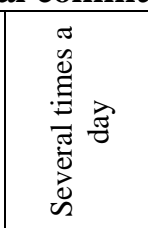 } & \multicolumn{2}{|c|}{ 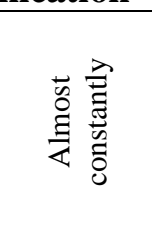 } & \multicolumn{2}{|c|}{ 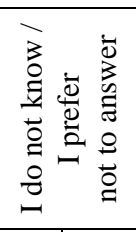 } & \multirow[t]{2}{*}{ 咅 } \\
\hline & $\mathrm{N}$ & $\%$ & $\mathrm{n}$ & $\%$ & $\mathrm{n}$ & $\%$ & $\mathrm{n}$ & $\%$ & $\mathrm{~N}$ & $\%$ & $\mathrm{~N}$ & $\%$ & $\mathrm{n}$ & $\%$ & \\
\hline \multirow{2}{*}{$\begin{array}{l}\text { I use the Internet to communicate } \\
\text { with foreigners }\end{array}$} & 140 & 59,07 & 47 & 19,83 & 8 & 3,38 & 14 & 5,91 & 2 & 0,84 & 26 & 10,97 & 0 & 0 & Poland \\
\hline & 168 & 73,04 & 14 & 6,08 & 15 & 6,52 & 11 & 4,78 & 12 & 5,21 & 10 & 4,34 & 0 & 0 & Ukraine \\
\hline
\end{tabular}

$59.07 \%$ of Polish and $73.04 \%$ of Ukrainian students have never or only several times communicated with foreigners on the Internet. $19.83 \%$ of Polish and $6.08 \%$ of Ukrainian respondents communicate with people from other countries once a month; $3.38 \%$ of Polish and $6.52 \%$ of Ukrainian students communicate with foreigners once a week; $5.91 \%$ of Poles and $4.78 \%$ of Ukrainians use the Internet for international communication daily or almost daily; $0.84 \%$ of Polish and $5.21 \%$ of Ukrainian students communicate with foreigners several times a day; $10.97 \%$ of Polish and $4.34 \%$ of Ukrainian students use the Internet for international communication almost constantly. In general, Polish respondents' rate of using the Internet for international communication is higher. We can assume that this is due to the lack of proficiency in foreign languages among Ukrainian students. But we have not found out the causes of low interest in this type of communication. Therefore, this problem needs further study.

The fifth question concerned young people's experience of communicating on the Internet with representatives of different ethnic and social communities. The results are presented in Table 5 (Source: Authors' own research).

Table 5. Use of the Internet to communicate with representatives of different ethnic and social communities

\begin{tabular}{|c|c|c|c|c|c|c|c|c|c|c|c|c|c|c|c|}
\hline \multirow[t]{2}{*}{ Question } & \multicolumn{2}{|c|}{ 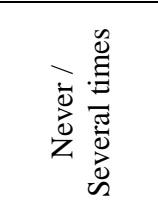 } & \multicolumn{2}{|r|}{ 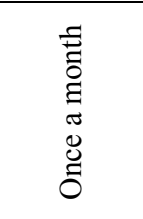 } & \multicolumn{2}{|r|}{ 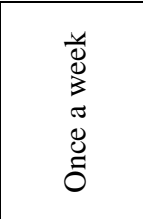 } & \multicolumn{2}{|c|}{ 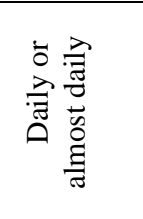 } & \multicolumn{2}{|c|}{ 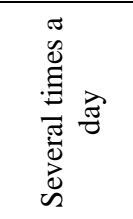 } & \multicolumn{2}{|c|}{ 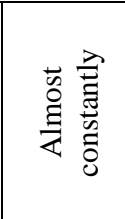 } & \multicolumn{2}{|c|}{ 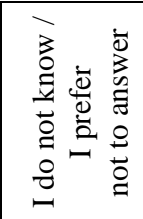 } & \multirow[t]{2}{*}{ 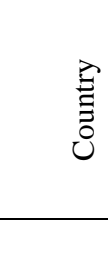 } \\
\hline & $\mathrm{N}$ & $\%$ & $\mathrm{n}$ & $\%$ & $\mathrm{n}$ & $\%$ & $\mathrm{n}$ & $\%$ & $\mathrm{~N}$ & $\%$ & $\mathrm{~N}$ & $\%$ & $\mathrm{n}$ & $\%$ & \\
\hline \multirow{2}{*}{$\begin{array}{l}\text { I communicate on the Internet } \\
\text { with foreigners, people of } \\
\text { different skin, race, religion, and } \\
\text { special needs }\end{array}$} & 18 & 7,59 & 64 & 27,00 & 62 & 26,16 & 51 & 21,52 & 24 & 10,13 & 6 & 2,53 & 12 & 5,06 & Poland \\
\hline & 162 & 70,43 & 14 & 6,08 & 11 & 4,78 & 14 & 6,08 & 10 & 4,34 & 4 & 1,73 & 15 & 6,52 & Ukraine \\
\hline
\end{tabular}

$7.59 \%$ of Poles and $70.43 \%$ of Ukrainians have never (or several times) communicated on the Internet with foreigners, people of different skin, race, religion, and special needs. $27 \%$ of Polish and $6.08 \%$ of Ukrainian students have communicated with this group of people once a month; $26.16 \%$ of Poles and $4.78 \%$ of Ukrainians have communicated once a week; $21.52 \%$ of Polish and $6.08 \%$ Ukrainian students - daily or almost daily; $10.13 \%$ of Poles and $4.34 \%$ of Ukrainians - several times a day; $2.53 \%$ of Polish and $1.73 \%$ of Ukrainian students communicate with this group of people almost constantly. 5.06\% of Poles and $6.52 \%$ of Ukrainians have not answered this question. According to the obtained data, Ukrainian students have less 
experience in communicating on the Internet with people of different colour, race, religion, people with special needs compared to Polish ones. In our view, this is explained by a more developed democratic society and higher social standards in Poland. The low level of use of digital technologies for communication by Ukrainians is of concern, which may indicate, on the one hand, the insufficient level of development of digital skills and, on the other hand, the lack of development of democratic values among Ukrainian respondents, in particular: tolerance, openness, equality.

The sixth question is related to student involvement in online communities. The data obtained are shown in Table 6 (Source: Authors' own research).

Table 6. Participation in online communities

\begin{tabular}{|c|c|c|c|c|c|c|c|c|c|c|c|c|c|c|c|}
\hline \multirow[t]{2}{*}{ Question } & \multicolumn{2}{|c|}{ 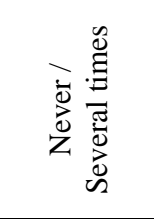 } & \multicolumn{2}{|r|}{ 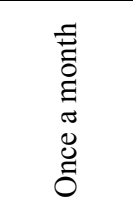 } & \multicolumn{2}{|c|}{$\begin{array}{l}\frac{y}{0} \\
0 \\
3 \\
0 \\
0 \\
0 \\
0\end{array}$} & \multicolumn{2}{|c|}{ 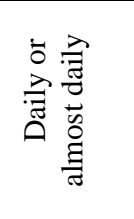 } & \multicolumn{2}{|c|}{ 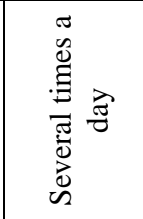 } & \multicolumn{2}{|c|}{ 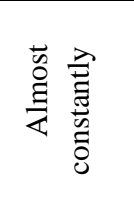 } & \multicolumn{2}{|c|}{ 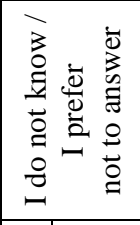 } & \multirow[t]{2}{*}{$\underset{\Xi}{\Xi}$} \\
\hline & $\mathrm{N}$ & $\%$ & $\mathrm{n}$ & $\%$ & $\mathrm{n}$ & $\%$ & $\mathrm{~N}$ & $\%$ & $\mathrm{~N}$ & $\%$ & $\mathrm{~N}$ & $\%$ & $\mathrm{n}$ & $\%$ & \\
\hline 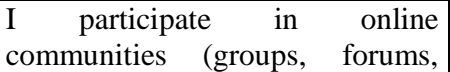 & 100 & 42,19 & 26 & 10,97 & 28 & 11,81 & 28 & 11,81 & 31 & 13,08 & 24 & 10,13 & 0 & 0 & Poland \\
\hline $\begin{array}{l}\text { etc.) where people share their } \\
\text { interests and views }\end{array}$ & 82 & 35,65 & 25 & 10,86 & 24 & 10,43 & 42 & 18,26 & 10 & 4,34 & 45 & 19,56 & 2 & 0,86 & Ukraine \\
\hline
\end{tabular}

42.19\% of Polish and 35.65\% of Ukrainian student youth have never or only several times participated in an online group where people share their interests, hobbies and views. $10.97 \%$ of Poles and $10.86 \%$ of Ukrainians are in online communities once a month. About one in ten Polish and Ukrainian students participate in such groups once a week (11.81\% of Poles and $10.43 \%$ of Ukrainians). $11.81 \%$ of Polish and $18.26 \%$ of Ukrainian students participate in online communities daily. $13.08 \%$ of Polish and $4.34 \%$ of Ukrainian students are on-line several times a day; $10.13 \%$ of Polish and $19.56 \%$ of Ukrainian are almost online in such communities. None of Polish and $0,86 \%$ of Ukrainian students have refused to answer this question.

The seventh question relates to the dissemination of self-created information in the network. The data obtained are presented in Table 7 (Source: Authors' own research).

Table 7. Dissemination of self-created information on the network

\begin{tabular}{|c|c|c|c|c|c|c|c|c|c|c|c|c|c|c|c|}
\hline \multirow[t]{2}{*}{ Question } & \multicolumn{2}{|c|}{ 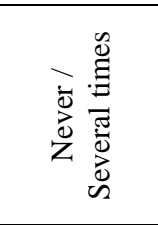 } & \multicolumn{2}{|r|}{ 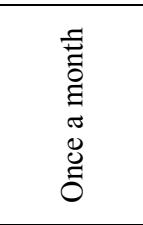 } & \multicolumn{2}{|r|}{$\begin{array}{l}u \\
0 \\
0 \\
0 \\
0 \\
0 \\
0 \\
0\end{array}$} & \multicolumn{2}{|c|}{ 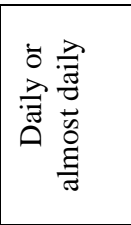 } & \multicolumn{2}{|c|}{ 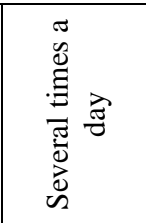 } & \multicolumn{2}{|c|}{ 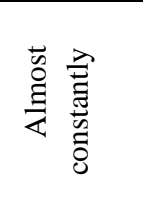 } & \multicolumn{2}{|c|}{ 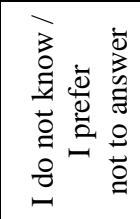 } & \multirow[t]{2}{*}{$\underset{\Xi}{\Xi}$} \\
\hline & $\mathrm{N}$ & $\%$ & $\mathrm{n}$ & $\%$ & $\mathrm{n}$ & $\%$ & $\mathrm{~N}$ & $\%$ & $\mathrm{~N}$ & $\%$ & $\mathrm{~N}$ & $\%$ & $\mathrm{n}$ & $\%$ & \\
\hline \multirow{2}{*}{$\begin{array}{l}\text { I disseminate information that } \\
\text { relates to my interests, views and } \\
\text { beliefs on the Internet in the form } \\
\text { of self-created images, videos, etc. }\end{array}$} & 121 & 51,05 & 61 & 25,74 & 14 & 5,91 & 16 & 6,75 & 1 & 0,42 & 16 & 6,75 & 8 & 3,38 & Poland \\
\hline & 133 & 57,82 & 21 & 9,13 & 32 & 13,91 & 13 & 5,65 & 4 & 1,73 & 22 & 9,56 & 5 & 2,17 & Ukraine \\
\hline
\end{tabular}

Information about the interests, views and beliefs in the form of self-created images, videos or presentations has never or only several times been shared by more than half of both Polish (51.05\%) and Ukrainian respondents (57.82\%). Information messages are created and disseminated in electronic networks once a month by $25.74 \%$ of Polish and $9.13 \%$ of Ukrainian recipients; $5.91 \%$ of Poles and $13.91 \%$ of Ukrainians - once a week; $6.75 \%$ of Polish and $5.65 \%$ of Ukrainian respondents - daily or almost daily; $0.42 \%$ of Polish and $1.73 \%$ of Ukrainian students - several times a day; $6.75 \%$ of Poles and $9.56 \%$ of Ukrainians - almost constantly. 3.38\% of Polish and $2.17 \%$ of Ukrainian students do not know the answer to this question.

The eighth question concerns the participation of young people in discussions of socio-political topics on the Internet. The results are shown in Table 8(Source: Authors' own research). 
Table 8. Conducting discussions on socio-political topics on the Internet

\begin{tabular}{|c|c|c|c|c|c|c|c|c|c|c|c|c|c|c|c|}
\hline \multirow[t]{2}{*}{ Question } & \multicolumn{2}{|c|}{ 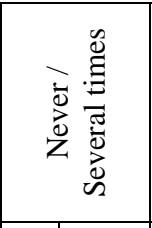 } & \multicolumn{2}{|r|}{ 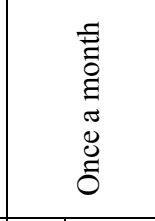 } & \multicolumn{2}{|r|}{$\begin{array}{l}\breve{0} \\
0 \\
\vdots \\
\sigma \\
0 \\
0 \\
0\end{array}$} & \multicolumn{2}{|c|}{ 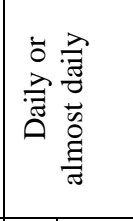 } & \multicolumn{2}{|c|}{ 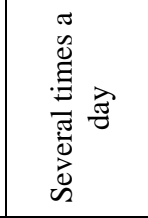 } & \multicolumn{2}{|c|}{ 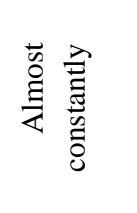 } & \multicolumn{2}{|c|}{ 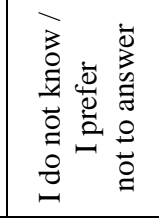 } & \multirow[t]{2}{*}{$\begin{array}{l}\vec{E} \\
\text { ठ }\end{array}$} \\
\hline & $\mathrm{N}$ & $\%$ & $n$ & $\%$ & $n$ & $\%$ & $\mathrm{~N}$ & $\%$ & $\mathrm{~N}$ & $\%$ & $\mathrm{~N}$ & $\%$ & $\mathrm{n}$ & $\%$ & \\
\hline \multirow{2}{*}{$\begin{array}{l}\text { I discuss online with others on } \\
\text { public and political topics }\end{array}$} & 14 & 62,03 & 44 & 18,57 & 16 & 6,75 & 8 & 3,38 & 6 & 2,53 & 8 & 3,38 & 8 & 3,38 & Poland \\
\hline & 15 & 65,65 & 40 & 17,39 & 25 & 10,86 & 2 & 0,86 & 2 & 0,86 & 5 & 2,17 & 5 & 2.17 & Ukraine \\
\hline
\end{tabular}

$62.03 \%$ of Polish and $65.65 \%$ of Ukrainian students have never or several times discussed public and political topics on the Internet. $18.57 \%$ of Poles and $17.39 \%$ of Ukrainians participate in social-political discussions in networks once a month; $6.75 \%$ of Poles and $10.86 \%$ of Ukrainians - once a week; $3.38 \%$ of Polish and $0.86 \%$ of Ukrainian respondents - daily or almost daily; $2.53 \%$ of Polish and $0.86 \%$ of Ukrainian students - several times a day; $3.38 \%$ of Polish students and $2.17 \%$ of Ukrainian students - almost constantly. $3.38 \%$ of Poles and $2.17 \%$ of Ukrainians did not answer this question.

The ninth question relates to the collaborative activity on the Internet. The results obtained are presented in Table 9 (Source: Authors' own research).

Table 9. Collaborative activity on the Internet

\begin{tabular}{|c|c|c|c|c|c|c|c|c|c|c|c|c|c|c|c|}
\hline \multirow[t]{2}{*}{ Question } & \multicolumn{2}{|c|}{ 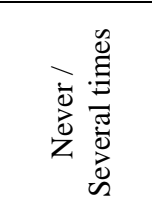 } & \multicolumn{2}{|r|}{$\begin{array}{l}\bar{\Xi} \\
\bar{\Xi} \\
\Xi \\
\tilde{J} \\
0 \\
0 \\
0\end{array}$} & \multicolumn{2}{|c|}{ 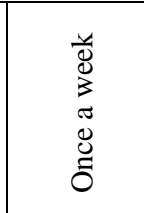 } & \multicolumn{2}{|c|}{ 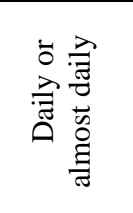 } & \multicolumn{2}{|c|}{ 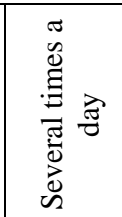 } & \multicolumn{2}{|c|}{ 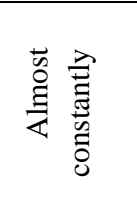 } & \multicolumn{2}{|c|}{ 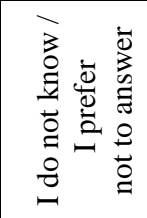 } & \multirow[t]{2}{*}{ 害 } \\
\hline & iv & $\%$ & 11 & $\%$ & & $\%$ & $\mathrm{~N}$ & 170 & $\mathrm{~N}$ & $\%$ & $\mathbf{N}$ & 10 & $\mathrm{n}$ & $\%$ & \\
\hline \multirow{2}{*}{$\begin{array}{l}\text { I am a member of a group or I } \\
\text { use special applications to work } \\
\text { in a joint project. }\end{array}$} & 14 & 60,76 & 26 & 10,97 & 16 & 6,75 & 19 & 8,02 & 7 & 2,95 & 11 & 4,64 & 14 & 5,91 & oland \\
\hline & 14 & 64,34 & 17 & 7,39 & 9 & 3,91 & 16 & 6,95 & 9 & 3,91 & 31 & 13,47 & 0 & 0 & Ukraine \\
\hline
\end{tabular}

$60.76 \%$ of Polish and $64.34 \%$ of Ukrainian respondents have never or several times been involved in collaborative activities. 10.97\% of Polish and $7.39 \%$ of Ukrainian students use the Internet once a month for the purpose of joint activity and $6.75 \%$ of Polish and $3.91 \%$ of Ukrainian students use the Internet for this purpose once a week; $8.02 \%$ of Poles and $6.95 \%$ of Ukrainians - daily or almost daily; $2.95 \%$ of Polish and $3.91 \%$ of Ukrainian respondents - several times a day; $4.64 \%$ of Polish and $13.47 \%$ of Ukrainian students almost constantly. $5.91 \%$ of Poles and none of Ukrainians did not answer this question.

The tenth question refers to the frequency of students completing educational tasks in the form of graphs, presentations, or videos. The results are presented in Table 10(Source: Authors' own research).

Table 10. Completing educational tasks in digital format

\begin{tabular}{|c|c|c|c|c|c|c|c|c|c|c|c|c|c|c|c|}
\hline \multirow[t]{2}{*}{ Question } & \multicolumn{2}{|c|}{ 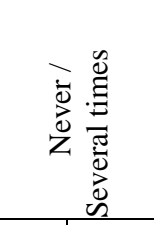 } & \multicolumn{2}{|r|}{ 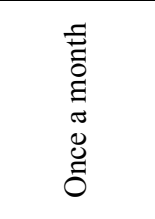 } & \multicolumn{2}{|r|}{$\begin{array}{l}\breve{d} \\
0 \\
\vdots \\
\pi \\
0 \\
0 \\
0\end{array}$} & \multicolumn{2}{|c|}{ 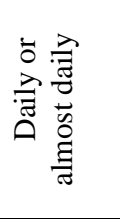 } & \multicolumn{2}{|c|}{ 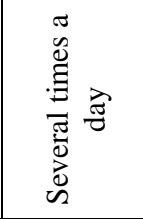 } & \multicolumn{2}{|c|}{ 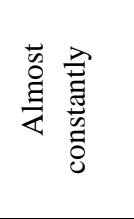 } & \multicolumn{2}{|c|}{ 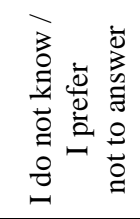 } & \multirow[t]{2}{*}{$\underset{\Xi}{\stackrel{\Xi}{\Xi}}$} \\
\hline & $\mathrm{n}$ & $\%$ & $\mathrm{n}$ & $\%$ & $\mathrm{n}$ & $\%$ & $\mathrm{~N}$ & $\%$ & $\mathrm{n}$ & $\%$ & $\mathrm{n}$ & $\%$ & $\mathrm{~N}$ & $\%$ & \\
\hline \multirow{2}{*}{$\begin{array}{l}\text { I perform educational tasks in the } \\
\text { form of graphs, presentations or } \\
\text { films }\end{array}$} & 76 & 32,07 & 79 & 33,33 & 39 & 16,46 & 11 & 4,64 & 8 & 3,38 & 8 & 3,38 & 16 & 6,75 & Poland \\
\hline & 109 & 47,39 & 37 & 16,08 & 32 & 13,91 & 19 & 8,26 & 8 & 3,47 & 16 & 6,95 & 9 & 3,91 & Ukraine \\
\hline
\end{tabular}

$32.07 \%$ of Polish and $47.39 \%$ of Ukrainian students have never or only several times completed digital learning tasks; $33.33 \%$ of Polish and $16.08 \%$ of Ukrainian students are engaged in such activity once a month, $16.46 \%$ of Polish and $13.91 \%$ of Ukrainian respondents are involved in this kind of tasks once a week; $4.46 \%$ of Polish and $8.26 \%$ of Ukrainian respondents make graphs, presentations or films daily or almost daily; $3.38 \%$ of Polish and $3.47 \%$ of Ukrainian students - several times a day; $3.38 \%$ of Polish and $6.95 \%$ of Ukrainian students - almost constantly. $6.75 \%$ of Poles and $3.91 \%$ of Ukrainians did not answer 
this question. The results obtained indicate that it is advisable to use digital technologies more widely in the educational process of both Polish and Ukrainian universities.

The analysis of the data obtained suggests that digital technologies can be used to support the development of young people's democratic values by enhancing their social and political activity in the digital space.

The ability of a majority of young Poles and Ukrainians to search, perceive and evaluate information through search engines and electronic social networks proves their rights of free access to information, their freedom of choice, and their activity in the network makes it possible to assess the level of formation of such value as information freedom (Table1-4).

Many young people, both Poles and Ukrainians, have the ability to use the Internet to exercise their right to their own point of view, to freely display their individuality and uniqueness, and it proves the students' values of self-expression and self-affirmation (Table 7-8).

Obtained data on the use of Internet technologies by Polish and Ukrainian students for successful communication with others show the feasibility of actively developing students' digital skills in order to support tolerant virtual interaction with people characterised by ethnic, linguistic, racial diversity (Table5-6).

The active participation of Polish and Ukrainian students in groups specially created in the electronic network in order to unite their efforts for organising collaborative social activity testifies to their awareness of the values of solidarity, equality. At the same time, it is advisable to enhance students' ability to engage in networking in order to complete common tasks (Table 9).

Data on the use of digital technologies by Polish and Ukrainian students in completing educational tasks prove the expediency of intensifying the use of innovative technological tools in formal and non-formal learning to ensure the democratic process of education (Table 10).

\section{Discussion and conclusions}

The authors of the paper came to the conclusion that the realisation of democratic values of youth should be considered in the discourse of personally significant use of digital technologies to ensure freedom, equality, openness, tolerance, solidarity in social interaction with other people. The analysis of the conducted studies has shown that the activity of Polish and Ukrainian student youth in the network is typologically related and promotes the development of their democratic values.

Professor Kenneth King of the University of Edinburgh argued that the formation of digital literacy of students doesn't guarantee the establishment of democratic values in the realities of life (King, 2019). According to the researcher, having gained wide access to information sources, a large part of British youth has become a target for "misinformation about citizenship, national identity, job security, migration threats, potential terrorism and a great deal else", which prompted young people to vote to leave the EU (p.292). The professor sees the solution to the problem in the expediency of forming critical digital literacy of students in formal and non-formal education.

We share the views of King(2019). After all, the results of our research confirm the widespread use of Internet resources by student youth in the process of forming political decisions. We agree that the formation of digital competence creates the conditions for democratic development of students, if at the same time they master the skills of critical analysis of information sources and messages.

The study of scientific results has made it possible to substantiate recommendations on the use of digital technologies to support the development of students' democratic values of formal and non-formal learning.

The digital space of the university, as a component of the blended education system, should be organised in such a way that students have ample opportunities to choose the necessary information, take an active part in creating and exchanging information messages. The creation of this space should be based on the functioning of digital university centres and with the participation of all subjects of formal and nonformal learning. An important component of this approach is to create learning cloud environments in which students can find the information they need, as well as complement the content of the cloud with own digital products.

The universal means of democratisation of the educational process is the designing of digital narratives by students (short films, video clips, photo frames, slide shows, sound files etc.), which promotes the formation of their XXI century skills - the so-called "4Cs" group: "Critical thinking", "Creativity" "Communication", "Collaboration" and. Creating digital narratives by students will give the realisation that any information in the network does not exist by itself, but created by a person and all messages are subjective in one way or another and require critical perception. Also, it will allow the young person to feel like an active creator of the digital space and open up great opportunities for communication and networking. 
Digital narratives are valuable in the context of the development of democratic values that reflect the author's point of view and aim at arguing and defending a particular position ( Leshchenko, Tymchuk, Ruban, 2017). For example, using one of the available video editors in his/her smartphone, a student should create a digital narrative of a particular topic for 1-3 minutes, post it on a shared blog, followed by discussion in a group. Stages of work might be: search on the Internet (selection of necessary photos, videos, illustrations), development of a script of narrative and creation of the textual accompaniment, presentation of the script plan of demonstration of visual materials according to the textual accompaniment, selection of musical material for sound design of a narrative, recording of the textual accompaniment using a voice recorder on your smartphone or computer, editing a narrative using an accessible video editor (a combination of screened visuals, music and recording text support). Recommended video editors might include: InShot, Quik, iMovie, DaVinci Resolve, Shotcut, Lightworks, OpenShot, Avidemux, etc. The next step is engaging students to discuss the created narratives in a joint chat by posting and commenting.

Web chat topics might include a wide range of issues related to the content of the discipline. It can be a discussion of certain concepts and definitions, phenomena and processes. In this way, the process of preparation and implementation of students' educational projects is also discussed. Each student who takes part in such a forum not only participates in the discussion of already "open" topics, but also can create their own thematic areas.

For democratisation of non-formal educational activities, access to the information posted on multimedia screens on the walls of university buildings, dormitories, on the websites of structural units, student self-government and student associations (official sites and social networking sites) plays an important role. We consider it advisable to fill this content with social advertisements that promote youth participation in socially important youth groups and associations, promote thematic internet resources, educational, artistic events (meetings, forums, conferences, charity events, concerts, exhibitions, etc.), organised both at the university and beyond and aimed at enhancing student social activity.

Democratisation of the digital space of the university will help create conditions for engaging students in virtual discussions of educational, cultural and artistic events: youth forums, conferences, congresses, concerts, exhibitions, book presentations, films, projects, etc. Creating thematic online communities on the platforms of Eventory, Eventmobi, OnePulse, Livewall, MailChimp, Poken, Slido, etc. ensures a rapid involvement of young people in a particular event, activates their own opinions and increases the ability to hear and analyse the views of others.

An effective way to support such forums and discussion groups might be a teacher's blog on a particular topic, a site with the opportunity to comment on the content or content group on the social network. Special services such as Slack may also be used for this purpose. This platform is not only convenient for sending messages on public channels, it also allows you to transfer images, PDFs and other documents directly in chat. It automatically indexes and archives any messages, notifications or files, and is not limited to the number of users.

For the formation of democratic values such as tolerance, equality, solidarity, it is important for the digital space of the university to be an open educational system that will make it possible to conduct scientific and educational activities in a global scale. In the aspect of further scientific research, the problem of using digital technologies to support the development of students' global critical competence as a determining value in the progress of human civilisation is needed.

\section{Acknoweledgement}

The research was funded by Lane Kirkland International Scholarship Program in Poland. The program is funded by the Polish-American Freedom Foundation and administered by the Leaders of Change Foundation. The author's participation in the program was carried out from October 2018 to June 2019 at the University of Marie Curie-Skłodowska in Lublin (scientific consultant - Professor A. Radomsky) and included internships at the University of Jan Kokhanowski (Piotrkow Trybunalski) and the Higher School economy in Radom. The purpose of the implemented research project was to study the Polish experience of transformation of society in the field of development of European values among young people by means of digital humanities.

\section{References}

Biuletyn Programu Stypendialnego im. Lane'a Kirklanda (2018). Polish-American Freedom Foundation. Retrieved from http://www.kirkland.edu.pl/kirkland2017/images/Biuletyny/33-Biuletyn-Programu-Kirklanda--www.pdf

Blayone,T.J., van Oostveen, R., Barber, W.,DiGiuseppe, M., Childs, E. (2017). Democratizing digital learning: theorizing the fully online learning community model. International Journal of Educational Technology in Higher Education,14(13). http://doi.org/10.1186/s41239-017-0051-4 
Bykov, V., \& Leshchenko, M. (2016).Digital humanistic pedagogy: relevant problems of scientific research in the field of using ICT in education. Information Technologies and Learning Tools, 53 (3), 1-17.https://doi.org/10.33407/itlt.v53i3.1417

Denek, K. (2008). Związek edukacji z wartościami[The relation between education andvalues]. In „Neodidagmata” 29/30 (pp. 25 38). Poznań: Adam Mickiewicz University Press. Retrieved from https://repozytorium.amu.edu.pl/bitstream/10593/3054/1/denek02.pdf

Gaisina, L., Mikhaylovskaya, I., Khairullina, N., Ustinova, O., \& Shakirova, E. (2015).The Role of the Media in the Spiritual and Moral Evolution of Society. Mediterranean Journal of Social Sciences, 6 (5). http://doi.org/10.5901/mjss.2015.v6n5s2p93

Hoshovska, V. A. (2013). Suspil'no-demokratychnitsinnosti -osnovaformuvannyaelity $v$ derzhavnomuupravlinni [Social and democratic values asthe basis of elite formation in public administration]. Kyiv: National academy of public administration under the President of Ukraine.Retrieved from http://academy.gov.ua/NMKD/library_nadu/Navch_Posybniky/83e5df5171d1-4384-8229-5f4987c2030e.pdf

Hrynko,V. (2019). Electronic social networking sites as a universal tool for developing future teachers' digital competence. Advanced Education, 12, 55-63.http://doi.org/10.20535/2410-8286.168076

Johnson, D. G. (2007).Democracy, Technology, and Information Societies.The Information Society: Innovation, Legitimacy, Ethics and Democracy, 233. https://doi.org/10.1007/978-0-387-72381-5_2

Karta praw podstawowych Unii Europejskiej. Dziennik Urzędowy Unii Europejskiej (2016). Retrieved from https://eurlex.europa.eu/legal-content/PL/TXT/HTML/?uri=CELEX:12016P/TXT\&from=PL

King, K. (2019). Education, digital literacy and democracy: the case of Britain's proposed 'exit' from the European Union (Brexit). Asia Pacific Educ. Rev., 20, 285-294. https://doi.org/10.1007/s12564-019-09594-0

Kostriukov, S. V.(2004). Formirovaniye demokraticheskikh tsennostey studencheskoy molodezhi $v$ transformatsionnyye period [Formation of democratic values of student youth in the transformation period].Unpublished $\mathrm{PhD}$ thesis, Institute of Higher Education APN Ukraine, Kyiv. Retrieved from http://catalog.library.tnpu.edu.ua:8080/library/DocDescription?doc_id=201536

Leshchenko, M., Tymchuk, L., \& Ruban, L. (2017). Digital Storytelling in a Foreign Language Classroom of Higher Educational Establishments.CEUR Workshop Proceedings, 1844, 428-439. Retrieved fromhttp://ceur-ws.org/Vol-1844/10000428.pdf

Nachmias, R., Mioduser, D., \& Shemla, A. (2001). Information and Communication Technologies Usage by Students in an Israeli High School: Equity, Gender, and Inside / Outside School Learning Issues. Education and Information Technologies, 6, 4353. https://doi.org/10.1023/A:1011367212148

Ordina, L. L.(2009). Democraticvaluesas a factorinthemotivationalsupportoftheuniversity'sculturalenvironment. Philosophy, Psychology, Pedagogy, 2, 142-146.

Polskie badanie EU Kids Online (2018). Biblioteka Cyfrowa. Retrieved fromhttps://fundacja.orange.p1/files/user_files/EU_Kids_Online_2019_v2.pdf

The European Values Study (2019). Retrieved from https://europeanvaluesstudy.eu/

Tymchuk, L.I. (2016). Tsyfrovi naratyvy v navchanni maybutnikh mahistriv osvity: istoriya, realiyi, perspektyvy rozvytku: monohrafiya [Digital narratives in teaching future Masters of Education: history, reality and prospects of development: monograph]. Kyiv, Ukraine: SAMMIT-KNYGA.

World Values Survey (2019). Retrieved from http://www.worldvaluessurvey.org/WVSContents.jsp

Received: March 11, 2020

Accepted: June 24, 2020 